\title{
METHODOLOGY FOR THE ASSESSMENT OF REGULATION COSTS IN THE BANKING MARKET
}

\author{
Kristaps FREIMANIS*, Maija ŠENFELDE \\ Department of the Territorial Development Management and Urban Economics, \\ Faculty of Engineering Economics and Management, Riga Technical University, \\ Kalnciema 6, LV-1048 Riga, Latvia
}

Received 01 March 2021; accepted 01 April 2021

\begin{abstract}
Purpose - In the field of the economics' regulation researchers so far have built the conceptual framework showing how the deadweight loss of market failures decrease and costs of the government intervention increase with the increased level of the government intervention. In order to quantify relationships between the level of intervention, intervention costs and the deadweight loss with econometric models it is important to understand how to quantify the regulation costs as a part of intervention costs. The objective of the research presented in this paper is to find the appropriate methodology for the quantification of the regulation costs in the banking market.
\end{abstract}

Research methodology - literature review (regarding theories), mathematical methods for quantification and econometric methods for validation purposes.

Findings - research shows that in the assessment of regulation costs three main stakeholders should be included - microprudential regulator, macroprudential regulator and financial regulation's policy maker. Research presents their cost assessment methodology. Its validation shows that in general methodology works as expected, i.e., higher government intervention levels lead to higher regulation costs, however this general rule has exceptions, which in authors' view indicates that other factors have an impact on the cost levels.

Research limitations - research shows how to assess the costs of main stakeholders based on the publicly available information. More precise view could be obtained if in the cooperation with authorities more details on certain cost items are received.

Practical implications - research results will be used to assess all government intervention costs (other positions include compliance costs and other indirect costs) and finalize the quantification of the framework. Quantified framework could be used for more precise policy making regarding the regulation of the banking market.

Originality/Value - research shows how to quantify the regulation costs of the banking market as currently there are only conceptual ideas.

Keywords: banking market, deadweight loss, intervention costs, market regulation, regulation costs.

JEL Classification: D60, G18.

Conference topic: Contemporary Financial Management.

\section{Introduction}

When market failure was introduced in the economic science, it was defined as incomplete competition. Later other types of market failures appeared in the scientific discussions, e.g., information failure, externalities etc. Currently market failures are recognized as justification for the government to intervene in the economy. Early thoughts on this intervention did not specify any certain limitations for this intervention. Most recent ideas though recognize importance of assigning limits for the government intervention as it has certain costs. So far the conceptual model (framework) has been built in the science and authors are currently researching on the approaches to quantify this conceptual model.

Government intervention costs have been classified in three categories - regulation costs, compliance costs and indirect costs. In this research paper authors present their approach on quantifying regulation costs. This approach

\footnotetext{
*E-mail: kristaps.freimanis_5@rtu.lv
}

(c) 2021 Authors. Published by Vilnius Gediminas Technical University. This is an open-access article distributed under the terms of the Creative Commons Attribution (http://creativecommons.org/licenses/by/4.0/) License, which permits unrestricted use, distribution, and reproduction in any medium, provided the original author and source are credited. 
includes certain steps in which relevant data and algorithms should be used to arrive to the assessment of given country's regulation cost level. Then methodology's validation is presented combining authors' previously developed methodology for the intervention level assessment and current methodology for the assessment of regulation costs.

\section{Government regulation costs: theoretical background}

\subsection{Market failures}

The first author who structured the discussion about market failures was Bator (1958) introducing definitions and types of market failures. Prior to Bator it was more common to discuss each market failure separately, in particular, incomplete competition expressed as the monopoly, e.g., in the work of Harberger (1954). At the moment there are several approaches how to classify market failures. All of them in one or another way include incomplete competition, incomplete information, externalities and public goods. Recently some additions to this list have appeared.

Two types of market failures - externalities and public goods - are often viewed together, e.g., works of Mankiw (2009), Besanko and Braeutigam (2011), Rubinfeld and Pindyck (2013), New South Wales government (NSW, 2017) as they reflect nature of the good. As per Mankiw (2009) an externality arises when a person engages in an activity that influences the well-being of a by-stander and yet neither pays nor receives any compensation for that effect. Public goods are characterized by excludability (whether people can be prevented from using the good) and rivalry in consumption (does one person's use of the good reduce another person's ability to use it). Separately under the topic of market structure another market failure - incomplete competition - is viewed, e.g., works of Mankiw (2009), Besanko and Braeutigam (2011), Jehle and Reny (2011), Rubinfeld and Pindyck (2013), New South Wales government (NSW, 2017). Information asymmetry, which gained its significance with Akerlof's "market for "lemons"” (1970), Spence's "job market's signals" (1973) and Stiglitz's "theory of "screening"” (1975), in the textbooks of microeconomics has received less attention and often is reflected in terms of moral hazard and adverse selection (e.g. Besanko \& Braeutigam, 2011; Jehle \& Reny, 2011; Rubinfeld \& Pindyck, 2013), while policy makers even add to the information asymmetry additional dimension of the information failure, e.g. New South Wales government (NSW, 2017). Rosengard and Stiglitz have named public goods as "incomplete markets" thereby more emphasizing the nature of market failure which has occurred there (Stiglitz, 2000; Rosengard \& Stiglitz, 2015). And on top of that they introduced less common market failure "unemployment and other macroeconomic disturbances". Although economists often recognize unemployment as a problem in the economy it is not so common to classify it as a market failure. In authors' view it is related to the fact that market failures are often viewed under the framework of microeconomics however Rosengard and Stiglitz have taken additional macroeconomic perspective there (Stiglitz, 2000; Rosengard \& Stiglitz, 2015).

In the financial market a great attention to the theory of market failures has been received after 2008's economic and financial crisis, e.g., in the works of Besley (2010), Allen and Carletti (2013), Grochulski and Morrison (2014). Special attention received necessity for the macroprudential regulation as systemic risks were identified on top of financial risks faced by individual companies (Allen \& Carletti, 2013; Grochulski \& Morrison, 2014).

\subsection{Government regulation}

Starting from Keynes (1936) government's role in the regulation of economics has been discussed. In those discussions government's intervention in the economy is justified by market failures that have been occurred (Arrow, 1970, 1985; Shubik, 1970; Ajefu \& Barde, 2015). Often normative approach is followed (Rosengard \& Stiglitz, 2015), when market failures prescribe what government should do in order to achieve Pareto efficiency in the market. The practical guidance often is provided in various policy documents (see Bjornstad \& Brown, 2004; NSW, 2017).

Initially no costs arising from the regulation were considered, however later this perspective appeared. Hertog (2010) in the analysis of previous research revealed three types of costs arising from the regulation (calling them as "intervention costs"): regulatory costs, compliance costs and indirect costs. These costs then were put into the context of welfare loss arising from market failures and the concept of the optimal level of welfare loss control were introduced (see Figure 1).

This concept shows how (a) the deadweight (welfare) loss of market failures decrease and (b) costs of the government intervention increase with the increased level of the government intervention. And in this vizualization it is

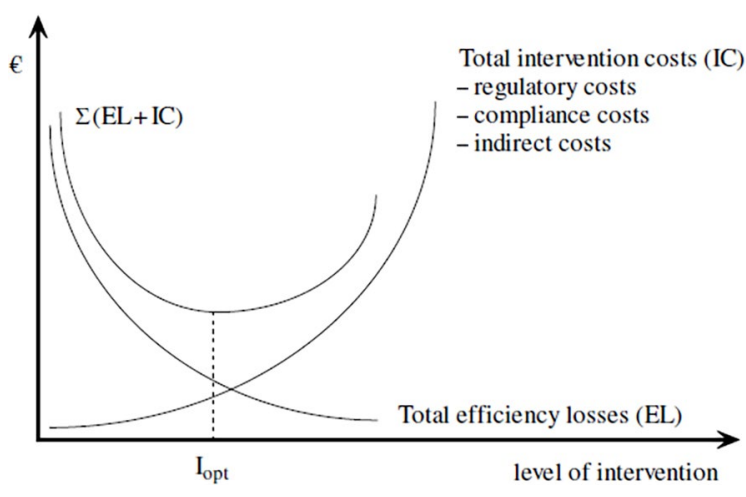

Figure 1. Optimal level of welfare loss control (source: Hertog, 2010) 
clearly shown that it is efficient to mitigate market failure till the point were costs arising from regulations are lower than the deadweight (welfare) loss. Hertog (2010) this point defines as "trade-off" between resources allocated to increasing levels of regulatory intervention and decreasing levels of inefficient firm behaviour.

\subsection{Government regulation costs}

Hertog (2010) as examples of government regulation costs mentions (a) information gathering costs for decision making on efficient price level for the firm, (b) monitoring costs of firm's behaviour and (c) enforcement of regulation costs. Meanwhile OECD for policy makers developed regulatory cost assessment guidance, which includes taxonomy of regulation costs (see Figure 2).

OECD define regulatory costs as all of the costs attributable to the adoption of a regulatory requirement, whether direct or indirect in nature and whether borne by business, consumers, government and its respective authorities (i.e., taxpayers) or other groups (OECD, 2014). As part of regulatory costs are regulation costs, i.e., costs borne by government. In the Figure 2 it corresponds to the label "Administration \& enforcement costs". OECD considers them into the category of compliance costs since they are directly related to the achievement of the underlying regulatory objective and are an unavoidable part of the cost of regulation. In OECD's view relevant cost items here are (a) the costs of publicising the existence of the new regulations, (b) developing and implementing new licensing or registration systems, (c) assessing and approving applications and processing renewals, (d) devising and implementing inspection and/or auditing systems and (e) developing and implementing systems of regulatory sanctions to respond to non-compliance. In recent years OECD has not published any updates regarding abovementioned methodology.

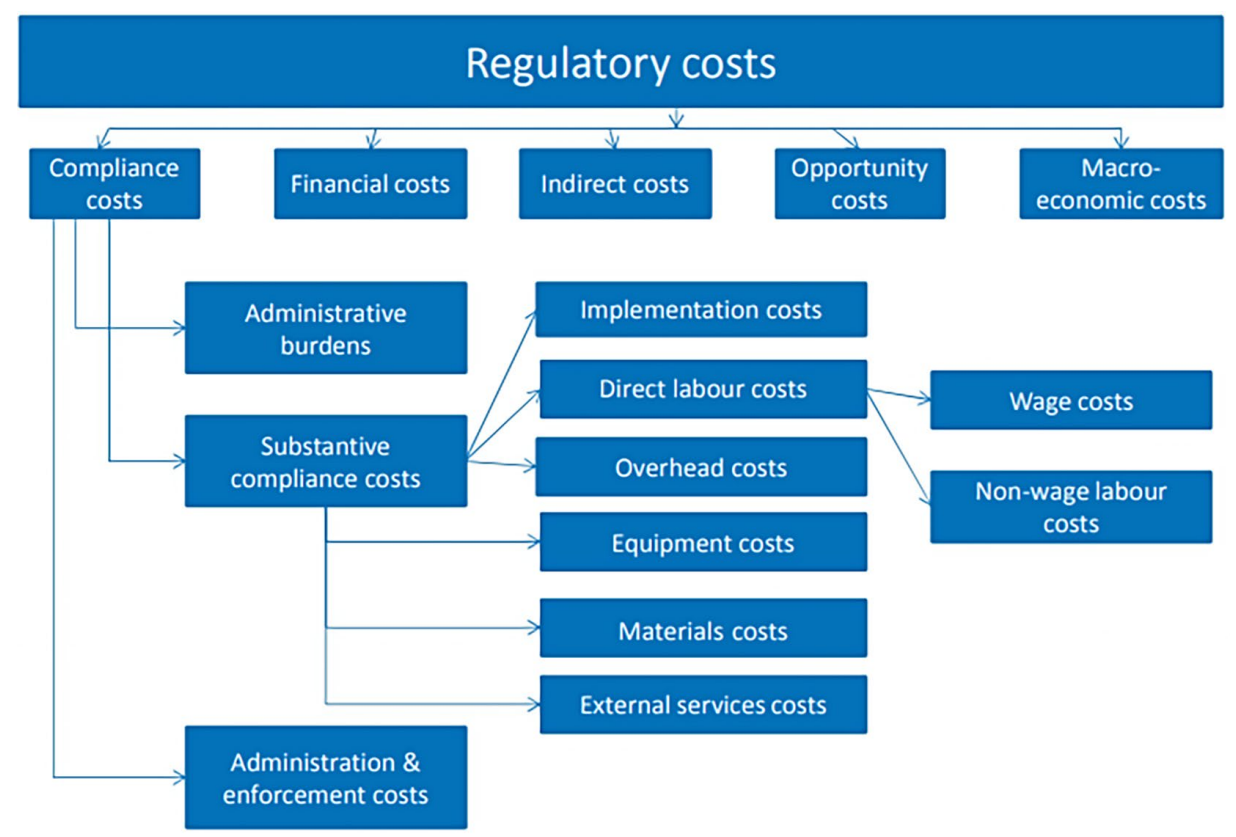

Figure 2. Taxonomy of regulation costs (source: OECD, 2014)

When it comes to the measurement of regulation costs Calomiris, Mamaysky, and Yang (2020) proposed the approach using natural language processing methods to measure the flow of regulation on the basis of the regulation's importance. In authors' view this approach is hard to apply to express the regulation depth in terms of currency.

Other authors have not paid much attention to the topic of government regulation costs. Both in the scientific literature and policy making discussions more focus has been put on the compliance cost assessment for individual firms, e.g., in the analysis done by Simkovic and Zhang (2019) quantification of regulation is done by tallying up the number of employees whose work has to do with regulatory compliance.

\section{Regulation costs' assessment in the banking market}

\subsection{Costs' assessment methodology}

Based on the input from previous research described above authors have developed the following regulation costs' assessment process (see Figure 3):

(a) Source Identification phase

a. Relevant authorities: currently in many countries there have been authorities appointed for microprudential 
regulation (firm level financial stability supervision) and macroprudential regulation (industry and economy level financial stability supervision), and authority appointed for policy making in the banking market (usually this authority is responsible for all financial market).

b. Relevant report: authorities prepare annual budget and/or annual financial report. As a data source annual financial report is preferred as it contains cost numbers referring to the costs actually occurred. For policy makers other approach is developed as publicly is not available information about budget numbers of certain departments within Ministry of Finance.

(b) Cost Selection phase

a. Relevant cost categories: (a) costs related to labour, including professional development (b) technology costs, (c) professional consultations, (d) public relations and (e) facilities related costs. There could be reasons requiring to exclude some items due to their irrelevance for the purpose of this assessment.

b. GDP for the year to be researched: this number will be used for further calculations described in the next phase.

(c) Calculation phase

a. Cost items from reports of microprudential and macroprudential regulators are summed up,

b. For policy maker the following approach has been developed: total staff costs are multiplied by $1 \%$ as on average financial market policy department is one of the 10 policy making departments within the Ministry of Finance and Ministry of Finance is one of the 10 ministries in the government.

a. Sum of costs are divided by GDP to have possibility to compare countries with different scale. Result is expressed in basis points due to the small number.

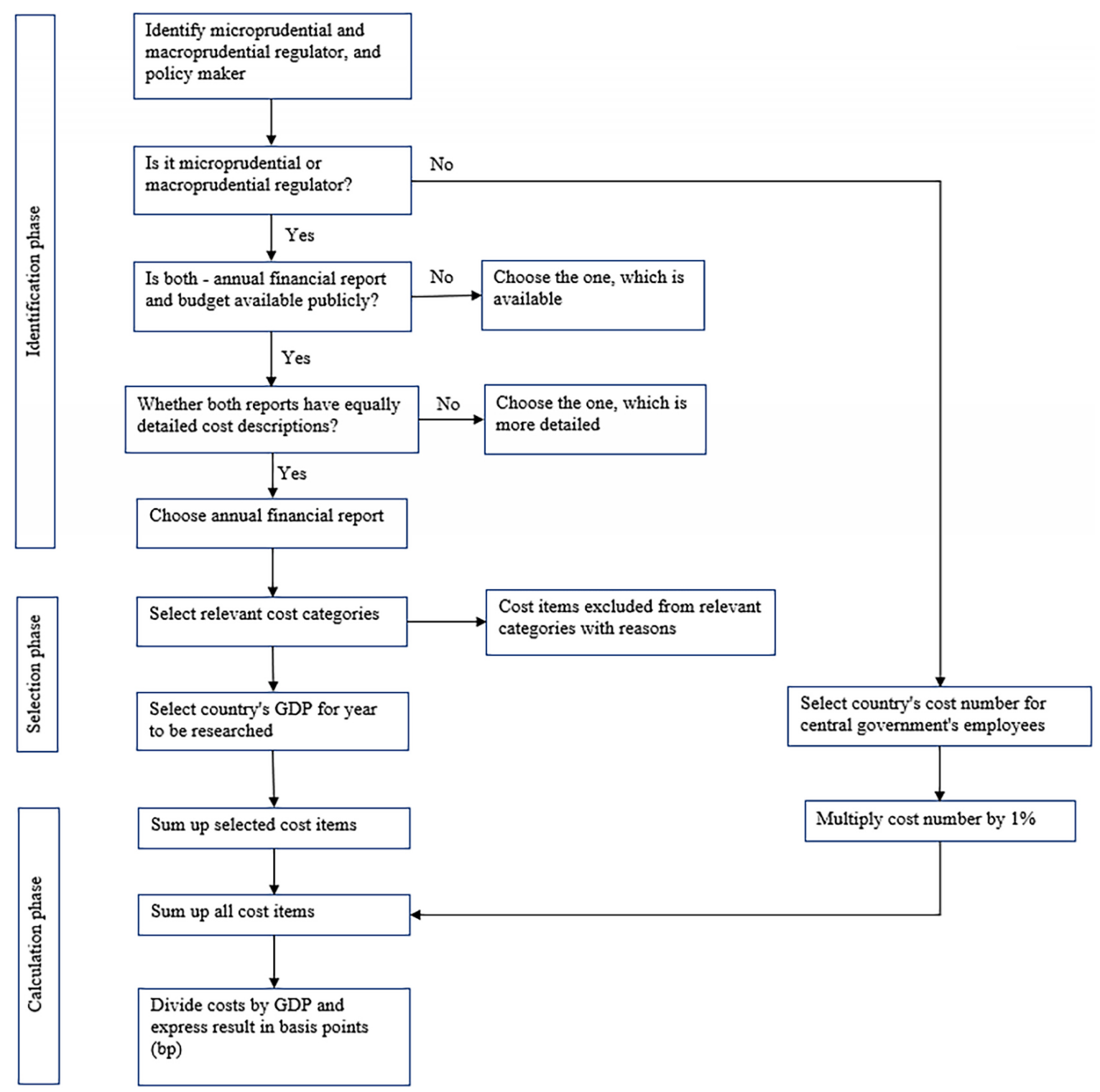

Figure 3. Regulation costs' assessment process flow chart (source: authors made) 


\subsection{Data for methodology validation}

In order to validate the methodology authors combined the concept described in Figure 1 and the process described in Figure 3. Based on previously developed methodology (Freimanis \& Šenfelde, 2020) authors have assessed the government intervention level in the countries of the European Union, the United Kingdom, the United States, Canada and Russia (see Table 1). This assessment has been combined with regulation cost assessment to test the function IC in the Figure 1. For this test the following countries were chosen to evaluate different levels of the government intervention: Lithuania (16), Estonia (18), Poland (14), Finland (20), Czech Republic (20), Denmark (12), Croatia (19), France (17). Choice of countries was based on several arguments to capture representative selection:

(a) countries with different levels of intervention,

(b) countries with different level of economic development,

(c) countries with different geographical location,

(d) for the highest level of intervention two countries were selected as they reported unexpectedly low regulation cost level (see Appendix, Table A1) so it was double-check on the relationship here.

Table 1. Intervention level of selected countries

(authors' made based on the developed methodology and source: World Bank, 2019)

\begin{tabular}{|l|c|l|c|}
\hline \multicolumn{1}{|c|}{ Country } & Intervention level, points & \multicolumn{1}{c|}{ Country } & Intervention level, points \\
\hline Austria & 18 & Belgium & 18 \\
\hline Bulgaria & 17 & Czech Republic & $\mathbf{2 0}$ \\
\hline Denmark & $\mathbf{1 2}$ & France & $\mathbf{1 7}$ \\
\hline Greece & 16 & Croatia & 19 \\
\hline Estonia & $\mathbf{1 8}$ & Ireland & 16 \\
\hline Italy & 18 & Cyprus & 16 \\
\hline Latvia & 19 & Lithuania & 14 \\
\hline Luxembourg & 18 & Malta & 18 \\
\hline Netherlands & 17 & Poland & 19 \\
\hline Portugal & 19 & Romania & 16 \\
\hline Slovakia & 17 & Slovenia & 19 \\
\hline Finland & $\mathbf{2 0}$ & Spain & 16 \\
\hline Hungary & 18 & Germany & 14 \\
\hline Sweden & 18 & United Kingdom & \\
\hline United States & 16 & Canada & \\
\hline Russia & 16 & & \\
\hline
\end{tabular}

Data for methodology validation (process in Figure 3) purposes has been retrieved from:

(a) relevant Financial Supervisory Authorities home pages (Finanšu un kapitāla tirgus komisija, n.d.; Finantsinspektsioon, n.d.; Komisja Nadzoru Finansowego, n.d.; FIN-FSA, n.d.; Financial Supervision Commission, n.d.; Danish Financial Supervisory Authority, n.d.; Autorité de contrôle prudentiel et de résolution, n.d.),

(b) central banks home pages (Latvijas Banka, n.d.; Lietuvos Bankas, n.d.; Eesti Pank, n.d.; Narodowy Bank Polski, n.d.; Suomen Pankki, n.d.; Bulgarian National Bank, n.d.; Danmarks Nationalbank, n.d.; Czech National Bank, n.d.; Croatian National Bank, n.d.; Banque de France, n.d.) and

(c) Eurostat (n.d.-a, n.d.-b) for the financial market policy making authority cost assessment and for GDP data tables in current prices.

In the Selection phase several cost items were excluded from relevant categories due to the following reasons:

(a) other period cost recharge with no details on reasons (1 case),

(b) one-off costs not related to business-as-usual (1 case).

Full table with results is enclosed in the Appendix Table A1.

\subsection{Function's IC test as methodology validation}

Authors based on the table in the Appendix Table A1 run the econometric test on the function IC, which explains relationship between government intervention level and regulation costs. If used polynomial function with order 3 , R-squared is exceeding 90\% (see Figure 4 and more details in Appendix, Table A2). 


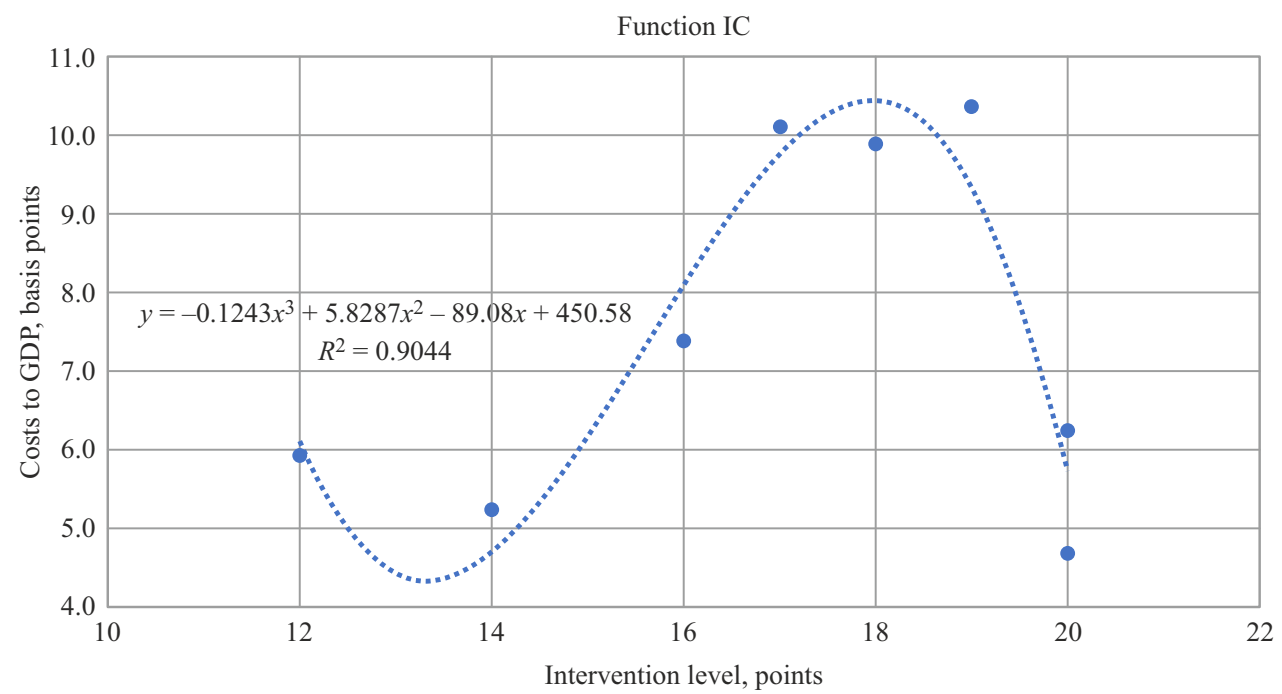

Figure 4. Correlation diagram (source: authors' made)

Function is as follows:

$$
y=-0.1243 x^{3}+5.8287 x^{2}-89.08 x+450.58,
$$

where: $y$ - regulation costs to GDP (basis points); $x$ - government intervention level (points), range [12; 20].

$\mathrm{R}$-squared for this function is $90.44 \%$, all orders of variable $x$ are statistically significant with probability $95 \%$ (see p-values in the Appendix Table A2).

Polynomial function with order 3 was suitable for function's assessment taking into account that countries with the highest level of government intervention (Finland, Czech Republic) reported comparably low intervention costs thereby functional relationship in the high-end changed which was not predicted by Hertog (2010). Polynomial function within specified range is the one able to capture such type of relationship.

\section{Conclusions}

Research shows that in general methodology works as expected, i.e., higher government intervention levels lead to higher regulation costs however an exception was captured: countries with the highest level of government intervention (Finland, Czech Republic) reported comparably low intervention costs thereby functional relationship in the high-end of government intervention scale changed which was not predicted by Hertog.

Current research has highlighted areas for further research:

(a) the general rule has exceptions, e.g., both Finland and Czech Republic reported unexpectedly low comparable costs of regulation despite high intervention level. In authors' view there are indications of other factors which have major impact on the result. One of them could be recently arising RegTech - technology solutions for more efficient regulator's activities,

(b) Many countries in the Table 1 report the same intervention level which indicates that methodology for intervention level assessment should be made more granular to distinguish countries and better assess function IC.

\section{Acknowledgements}

Authors thank very much to Katrīne Ustinoviča, former Bachelor degree student in Riga Technical University who helped to collect data for the assessment reflected in the Table 1.

\section{Disclosure statement}

Authors declare that they do not have any competing financial, professional, or personal interests from other parties. 
K. Freimanis, M. Šenfelde. 2021. Methodology for the assessment of regulation costs in the banking market

\section{References}

Ajefu, J. B., \& Barde, F. (2015). Market efficiency and government intervention revisited: What do recent evidence tell us? Journal of International Business and Economics, 3(1), 20-23. https://doi.org/10.15640/jibe.v3n1a3

Akerlof, G. A. (1970). The market for "lemons": Quality uncertainty and the market mechanism. The Quarterly Journal of Economics, 84(3), 488-500. https://doi.org/10.2307/1879431

Allen, F., \& Carletti, E. (2013). Systemic risk from real estate and macro-prudential regulation. International Journal of Banking, Accounting and Finance, 5(1/2), 28-48. https://doi.org/10.1504/IJBAAF.2013.058091

Arrow, K. J. (1970). The organization of economic activity: Issues pertinent to the choice of market versus nonmarket al.ocation. Public expenditure and policy analysis (pp. 67-81). Rand MacNally College Publishing Company, Chicago.

Arrow, K. J. (1985). The potentials and limits of the market in resource allocation. In G. R. Feiwel (Ed.), Issues in contemporary microeconomics and welfare (pp. 107-124). Palgrave Macmillan. https://doi.org/10.1007/978-1-349-06876-0_2

Autorité de contrôle prudentiel et de résolution. (n.d.). Annual financial reports of the French Financial Supervisory Authority. https://acpr.banque-france.fr/en/liste-chronologique/acpr-annual-reports?year=2020

Banque de France. (n.d.). Annual financial reports of the Bank of France. https://www.banque-france.fr/en/liste-chronologique/ banque-de-france-annual-report

Bator, F. M. (1958). The anatomy of market failure. The Quarterly Journal of Economics, 72(3), 351-379. https://doi.org/10.2307/1882231

Besanko, D., \& Braeutigam, R. (2011). Microeconomics (4 ${ }^{\text {th }}$ ed., parts 1, pp. 4-7). John Wiley \& Sons, Inc.

Besley, T. (2010). How do market failures justify interventions in rural credit markets? The World Bank Research Observer, 9(1), 27-47. https://doi.org/10.1093/wbro/9.1.27

Bjornstad, D. J., \& Brown, M. A. (2004). A market failures framework for defining the government's role in energy efficiency (Working paper JIEE 2004-02). Joint Institute for Energy and Environment.

Bulgarian National Bank. (n.d.). Annual financial reports of the Bank of Bulgaria. https://www.bnb.bg/ResearchAndPublications/ PubPeriodical/PubPAnnualReport/index.htm

Calomiris, C. W., Mamaysky, H., \& Yang, R. (2020). Measuring the Cost of Regulation: A Text-Based Approach. (NBER Working Papers no. 26856). National Bureau of Economic Research. https://doi.org/10.3386/w26856

Croatian National Bank. (n.d.). Annual financial reports of the Bank of Croatia. https://www.hnb.hr/en/about-us/financial-statements

Czech National Bank. (n.d.). Annual financial reports of the Bank of Czech Republic. https://www.cnb.cz/en/about_cnb/performance/financial-statements/

Danish Financial Supervisory Authority. (n.d.). Annual fees for the Danish Financial Supervisory Authority. https://www.dfsa.dk/ About-us/Tasks-of-the-Danish-FSA/Payment-of-fees

Danmarks Nationalbank. (n.d.). Annual financial reports of the Bank of Denmark. https://www.nationalbanken.dk/en/publications/ Pages/2020/03/Annual-Report-2019.aspx

Eesti Pank. (n.d.). Annual financial reports of the Bank of Estonia. https://www.eestipank.ee/en/publications/series/annual-report

Eurostat. (n.d.-a). GDP at market prices. https://ec.europa.eu/eurostat/databrowser/view/tec00001/default/table?lang=en

Eurostat. (n.d.-b). General government expenditure by function (COFOG). https://ec.europa.eu/eurostat/databrowser/view/GOV 10A EXP custom 621883/default/table?lang=en

Financial Supervision Commission. (n.d.). Annual financial reports of the Bulgarian Financial Supervisory Authority. https://www. fsc.bg/en/about-fsc/fsc-reports/

Finanšu un kapitāla tirgus komisija. (n.d.). Annual financial reports of the Latvian Financial and Capital Market Commission. https://www.fktk.lv/par-mums/gada-parskati/

Finantsinspektsioon. (n.d.). Annual financial reports of the Estonian Financial Supervisory Authority. https://www.fi.ee/en/teema/ yearbook

FIN-FSA. (n.d.). Annual financial reports of the Finnish Financial Supervisory Authority. https://www.finanssivalvonta.fi/en/publications-and-press-releases/annual-reports/

Freimanis K., \& Šenfelde, M. (2020). Approach of Scaling the Level of Government Intervention in the Financial Market. In 11th International Scientific Conference "Business and Management 2020”. Vilnius, Lithuania. https://doi.org/10.3846/bm.2020.591

Harberger, A. C. (1954). Monopoly and resource allocation. The American Economic Review, 44(2), 77-87.

Hertog, J. (2010). Review of economic theories of regulation (Discussion Paper Series 10-18). Tjalling C. Koopmans Research Institute.

Grochulski, B., \& Morrison, W. (2014). Understanding market failure in the 2007-08 Crisis. Economic Brief of Federal Reserve Bank of Richmond, EB14-12.

Jehle, G. A., \& Reny, P. J. (2011). Advanced microeconomic theory ( $3^{\text {rd }}$ ed., chapters 4, 8). Pearson Education Limited.

Keynes, J. M. (1936). The general theory of employment, interest and money. Palgrave Macmillan.

Komisja Nadzoru Finansowego. (n.d.). Annual financial reports of the Polish Financial Supervisory Authority. https://www.knf. gov.pl/en/ABOUT_US/KNF_Office/Reports_on_activites

Latvijas Banka. (n.d.). Annual financial reports of the Bank of Latvia. https://www.bank.lv/par-mums/parskati/finansu-parskati

Lietuvos Bankas. (n.d.). Annual financial reports of the Bank of Lithuania. https://www.lb.lt/en/reviews-and-publications/category.38/series.201

Mankiw, N. G. (2009). Principles of microeconomics (5 ${ }^{\text {th }}$ ed., parts 2-5). South-Western Cengage Learning.

Narodowy Bank Polski. (n.d.). Annual financial reports of the Bank of Poland. https://www.nbp.pl/homen.aspx?f=/en/publikac$\mathrm{je} / \mathrm{r} \_$roczny/r_roczny.html 
NSW. (2017). Market failure guide. A guide to categorising market failures for government policy development and evaluation. State of New South Wales through Department of Industry.

OECD. (2014). OECD regulatory compliance cost assessment guidance. OECD Publishing. https://doi.org/10.1787/9789264209657-en

Rosengard, J. K., \& Stiglitz, J. E. (2015). Economics of the public sector ( $4^{\text {th }}$ ed., chapter 4). W. W. Norton \& Company, Inc.

Rubinfeld, D. L., \& Pindyck, R. S. (2013). Microeconomics ( $8^{\text {th }}$ ed., parts 1, 4). Pearson Education, Inc.

Shubik, M. (1970). On different methods for allocating resources. Kyklos, 23(2), 332-337. https://doi.org/10.1111/j.1467-6435.1970.tb02562.x

Simkovic, M., \& Zhang, M. B. (2019). Measuring regulation. In Conference Proceedings of Summer Institute 2019 Law and Economics, Boston, USA. http://conference.nber.org/conf_papers/f125600.pdf

Spence, M. (1973). Job market signaling. The Quarterly Journal of Economics, 87(3), 355-374. https://doi.org/10.2307/1882010 Stiglitz, J. E. (1975). The theory of "screening", education, and the distribution of income. American Economic Review, 65(3), 283-300.

Stiglitz, J. E. (2000). Economics of the public sector ( $3^{\text {rd }}$ ed., chapter 4). W. W. Norton \& Company, Inc.

Suomen Pankki. (n.d.). Annual financial reports of the Bank of Finland. https://www.suomenpankki.fi/en/media-and-publications/ publications/annual-report/

World Bank. (2019). Bank regulation and supervision survey. https://www.worldbank.org/en/research/brief/BRSS

\section{APPENDIX}

Table A1. Data for methodology validation (year 2019)

\begin{tabular}{|l|c|c|c|c|c|c|c|}
\hline 2019 & $\begin{array}{c}\text { Intervention } \\
\text { level points }\end{array}$ & $\begin{array}{c}\text { Microprudentional } \\
\text { supervisor, } \\
\text { mln. EUR }\end{array}$ & $\begin{array}{c}\text { Macroprudentional } \\
\text { supervisor, } \\
\text { mln. EUR }\end{array}$ & $\begin{array}{c}\text { Policy } \\
\text { maker, } \\
\text { mln. EUR }\end{array}$ & $\begin{array}{c}\text { Total } \\
\text { regulation } \\
\text { costs, mln. } \\
\text { EUR }\end{array}$ & $\begin{array}{c}\text { GDP at } \\
\text { current } \\
\text { prices, mln. } \\
\text { EUR }\end{array}$ & $\begin{array}{c}\text { Total } \\
\text { regulation } \\
\text { costs, bp } \\
\text { to GDP }\end{array}$ \\
\hline Lithuania & 16 & & 33.9 & 2.2 & 36.1 & 48797.4 & 7.4 \\
\hline Estonia & 18 & 7.0 & 19.6 & 1.3 & 27.8 & 28112.4 & 9.9 \\
\hline Poland & 14 & 37.1 & 219.9 & 21.0 & 278.0 & 532329.2 & 5.2 \\
\hline Finland & 20 & 34.8 & 108.0 & 7.4 & 150.2 & 240561.0 & 6.2 \\
\hline $\begin{array}{l}\text { Czech } \\
\text { Republic }\end{array}$ & 20 & & 96.9 & 7.8 & 104.7 & 223950.3 & 4.7 \\
\hline Denmark & 12 & 54.1 & 122.2 & 9.3 & 185.7 & 312747.2 & 5.9 \\
\hline Croatia & 19 & & 53.1 & 3.0 & 56.2 & 54237.9 & 10.4 \\
\hline France & 17 & 187.6 & 2154.0 & 107.8 & 2449.4 & 2425708.0 & 10.1 \\
\hline
\end{tabular}

Table A2. Function's IC test

\section{SUMMARY OUTPUT}

\begin{tabular}{|l|c|}
\hline \multicolumn{2}{|c|}{ Regression Statistics } \\
\hline Multiple R & 0.951 \\
\hline R Square & 0.904 \\
\hline Adjusted R Square & 0.833 \\
\hline Standard Error & 0.951 \\
\hline Observations & 8 \\
\hline
\end{tabular}

ANOVA

\begin{tabular}{|l|c|c|c|c|c|}
\hline & $d f$ & $S S$ & $M S$ & $F$ & Significance $F$ \\
\hline Regression & 3 & 34.257 & 11.419 & 12.613 & 0.017 \\
\hline Residual & 4 & 3.621 & 0.905 & & \\
\hline Total & 7 & 37.878 & & & \\
\hline
\end{tabular}

\begin{tabular}{|l|c|c|c|c|c|c|}
\hline & Coefficients & Standard Error & $t$ Stat & $P$-value & Lower 95\% & Upper 95\% \\
\hline Intercept & 450.577 & 108.265 & 4.162 & 0.014 & 149.986 & 751.167 \\
\hline X Variable 1 & -89.080 & 20.755 & -4.292 & 0.013 & -146.703 & -31.456 \\
\hline X Variable 2 & 5.829 & 1.304 & 4.471 & 0.011 & 2.210 & 9.448 \\
\hline X Variable 3 & -0.124 & 0.027 & -4.628 & 0.010 & -0.199 & -0.050 \\
\hline
\end{tabular}

